\title{
Transformation of Approaches to Determine Influence Factors in the Economic Development Models
}

\author{
Submitted 14/02/19, 1st revision 02/03/19, 2nd revision 15/03/19, accepted 25/4/19
}

\author{
M.M. Ihnatenko ${ }^{1}$, L.O. Marmul' ${ }^{2}$, D.S. Ushakov ${ }^{3}$, S.P. Kuchyn ${ }^{4}$
}

\begin{abstract}
:
Purpose: The research paper deals with the development of new scientific solutions regarding the identification of influence factors in the economic development models for developed and developing countries. The paper emphasizes the key significance of modelling within the framework of the study of economic growth at the level of world, national and regional economies (macro- and mesolevel).

Design/methodology/approach: To achieve the objectives of this study the main components of economic development models were discussed.

Findings: The transformation of the approaches of scholars to identify the influence factors within the historical change of the economic development models is noted. It was emphasized that the overwhelming majority of scholars use three factors of influence (land, labour, capital) and their derivatives in the "old", "new" and regional economic development models, which is insufficient in the current conditions of economic systems at the macro-and mesolevel.

Practical implications: Two related economic development models for developed countries and developing countries are proposed for use; key influence factors within these models are identified.

Originality/value: It is emphasized that capital, human resources, level of innovations and competitive advantages are important for ensuring the economic development of developed countries, and the level of corruption and the level of the shadow economy are added to the above-mentioned components for developing countries.
\end{abstract}

Keywords: Economic development, regional models, influence factors.

JEL code: O10.

Paper type: Research article.

${ }^{I}$ SHEI «Pereiaslav-Khmelnytskyi Hryhorii Skovoroda State Pedagogical University», Financial and Humanitarian Faculty, Department of Economic, Ukraine.

${ }^{2}$ SHEI «Pereiaslav-Khmelnytskyi Hryhorii Skovoroda State Pedagogical University»,

Financial and Humanitarian Faculty, Department of Economic, Ukraine.

${ }^{3}$ Corresponding author, Suan Sunandha Rajabhat University, Bangkok, Thailand,

Denis.us@ssru.ac.th

${ }^{4}$ Luhansk National Agrarian University, Faculty of Economics, Department of Economics of Enterprise, Marketing and Economic Theory, Starobilsk, Ukraine. 


\section{Introduction}

Transformation of the world economy requires single-direction economic development of all countries. This should be the key to the long-term effective development of the world and national economic systems, as well as to reduction of the difference between developed and developing countries. At the same time, we note significant problems in such development, where:

- Economically developed countries faced the problem of inhibition of their economic systems;

- Developing countries are divided into three large groups depending on their economic development problems, namely: some countries have a rapidly developing economy (China, India) and they should regulate such development on an ongoing basis in order to prevent the reduction in the effectiveness of both national economy as a whole and its individual elements in particular; most of these countries have problems with the chaotic development of economic systems and are struggling with persistent crises (Argentina, Ukraine, etc.); the last group of countries faced with the lack of development and conservation of their own economic problems (Afghanistan, African countries, etc.). In this context, we agree with Beck (2005), who points out that a new era has begun, where the rules of the old era must be taken into account, although they have lost their strength. The above points to the need to find new ways of developing economic systems, where modelling of this development should be the main element.

It should be noted that the problems of economic development began to be considered from the days of Mesopotamia (Kurz and Salvadori, 2003) and received the first scientific substantiation in the works of Thomas Robert Malthus (1836). Subsequently, A. Smith (1776) and D. Ricardo (1951) initiated the search for key factors influencing economic development and modelling the results obtained (Piętak, 2014). Significant transformational processes in the world and national economic systems in the first half of the 20th century led to an increase in scientific research in the direction of modelling economic development, which, together with the achievements of the classical school of political economy, formed a set of so-called "old" models of economic growth based on a limited number of influence factors (Chen and Mehlenbacher, 2010; Anushree, 2019).

Substantial changes in the world economy and economies of individual countries, the development of globalization, the transition to the post-industrial type of the formation of national economic systems in the second half of the 20th century and, especially, at the beginning of the 21 st century, led to a significant increase in the number of economic development models based on a much greater number of influence factors and were called "new" models (Sharipov, 2015; Loubaki, 2017; Yao, 2019). At the same time, we note a significant 
scientific discussion on the influence factors that are included in the economic development model and the need for their critical assessment based on the study of transformation approaches to the development of such models, taking into account historical chronology and modern theoretical and practical needs for describing and predicting the development of economic systems at the world, national and regional levels, which is the objective of the authors' research. Proceeding from a set objective, it is important to prove or refuse a number of hypotheses, namely:

- the study of economic development has taken place since the times of ancient civilizations and has been widely spread with the development of capitalism in the 19th, 20th and 21st centuries, following the path of the complexity of theoretical developments and the use of appropriate models that occupy a central place in scientific studies on economic development;

- the old economic development models were based on a limited number of influence factors, thus limiting their theoretical and practical significance;

- new economic development models are based on a much greater number of factors, which allows improving their adaptation to the current conditions of functioning of the world and national economies;

- modern regional development models have differences in influence factors which take into account the scale of their use;

- the development of global, national and regional systems requires the development of new economic development models based on key modern influence factors taking into account the achievements of scholars in the "old" and "new" models.

\section{Materials and methods}

To achieve the objective of this research paper, a system of general scientific research methods and research methods at the empirical and theoretical levels were used, namely: the method of comparison for the critical assessment of approaches to the definition of the influence factor in economic development models; abstraction method to identify problems of using influence factors in economic development models; the method of induction to find key influence factors that can be used in modern economic development models of developed and developing countries; methods of systematization, grouping and logical generalization for systematization of information, drawing conclusions and scientific proposals of the research paper.

The methodology of the study is based on the historical and systemic approach in revealing and resolving the problems of transformation of influence factors in economic development models and the choice of the most key factors for modern models of this development. In this work, modelling is presented as one of the main elements of the study of economic growth at the macro- and mesolevels (world, national and regional economic systems). The study is also based on the 
assumption that the selection of the most important influence factors will improve the efficiency of modelling economic growth in practice for developed and developing countries.

\section{Results}

\subsection{Economic Development: Nature, Theoretical Characteristics, Role and Place of Modelling}

The problem of the development of natural or artificial systems, especially the economic development systems, has always been of interest to scholars and economists - practitioners. At the same time, based on the chronology of such studies, we can identify a number of their key stages and describe them (Figure 1).

Figure 1. Stages of the study of economic development and their brief description 


\begin{tabular}{|c|c|}
\hline $\begin{array}{l}\text { Origins (Ancient Egypt, } \\
\text { Mesopotamia, Greece, } \\
\text { Roman Empire) }\end{array}$ & $\begin{array}{l}\text { Focus on the practice and study of the conditions for } \\
\text { increasing production at both individual farms and at the } \\
\text { country level }\end{array}$ \\
\hline 5 & \\
\hline $\begin{array}{c}\text { Revival of interest }\left(17^{\text {th }}-\right. \\
\left.19^{\text {th }} \text { centuries }\right)\end{array}$ & $\begin{array}{l}\text { Attempts to explain the causes of economic growth and its } \\
\text { limiting factors as well as the boundaries. Mostly at the level } \\
\text { of a separate national economy with an emphasis on } \\
\text { theoretical developments. First attempts to develop models. }\end{array}$ \\
\hline 5 & \\
\hline $\begin{array}{l}\text { Formation of a clear } \\
\text { theoretical base (the first } \\
\text { half of the } 20^{\text {th }} \text { century) }\end{array}$ & $\begin{array}{l}\text { Study of the causes and features of economic growth taking } \\
\text { into account the crisis manifestations in the world and } \\
\text { national economies. The growth of the number of economic } \\
\text { growth models and a rigorous scientific discussion of their } \\
\text { use and influence factors. Emphasis on theoretical } \\
\text { developments. }\end{array}$ \\
\hline 5 & \\
\hline $\begin{array}{l}\text { The emergence of new } \\
\text { scientific statements based } \\
\text { on criticism of the } \\
\text { established theoretical basis } \\
\text { (the second half of the } 20^{\text {th }} \\
\text { century) }\end{array}$ & $\begin{array}{l}\text { Study of the causes and features of economic growth taking } \\
\text { into account the transformational processes in the world and } \\
\text { national economies. The emergence of "new" economic } \\
\text { growth models and a rigorous scientific discussion about } \\
\text { their use and influence factors. Attempts to combine } \\
\text { theoretical developments with practice. }\end{array}$ \\
\hline 5 & \\
\hline $\begin{array}{l}\text { Shifting emphasis to } \\
\text { regionalism, ensuring the } \\
\text { sustainable development of } \\
\text { individual national economies } \\
\text { and reducing the gap between } \\
\text { developed and developing } \\
\text { countries (the beginning of the } \\
19^{\text {th }} \text { century) }\end{array}$ & $\begin{array}{l}\text { Study of the causes and features of economic growth at } \\
\text { the world, national and regional levels. The emergence of } \\
\text { "new" economic growth models with an emphasis on } \\
\text { ensuring the growth of the economies of developing } \\
\text { countries. Shift of emphasis on the use of economic } \\
\text { development models in practice. }\end{array}$ \\
\hline
\end{tabular}

*Compiled by the authors based on: Kurz and Salvadori, 2003; Piętak, 2014; Sharipov, 2015; Díaz-Bautista and González-Andrade, 2014; Moroianu, 2012; Sanderson, 1992.

When revealing the nature of "economic development", it is necessary to clearly understand that this concept is based on the term "development", which scientists understand either as a process of improving the relevant material systems (Shutler, 2016), or as a process of establishing a public infrastructure to stimulate the growth of relevant material systems (Walker, 2013). The modern interpretation of economic development also takes into account such concepts as "sustainable development" and "harmonious development". It is common to understand sustainable development as the statement at the United Nations Conference on Environment and Development (1992) that the satisfaction of the current needs of consumers of the economic system should be without prejudice to the needs of future consumers of the same system (Leggett and Carter, 2012). 
As for the harmonious development, A. Smith (1776) also studied this issue, who pointed to the natural harmony, which was reflected in the "invisible hand" that stabilizes the market, as well as Proudhon (1846), who emphasized the factors violating the harmony of production growth. Given the above, it is possible to formulate a graphical interpretation of the term of "economic development" (Figure 2 ). It is necessary to provide several explanations within the theoretical description of the term "economic development":

- the microlevel of economic systems shall be understood as households and business entities, mesolevel - as sectors of the economy of the country and the economy of individual regions of the state; macrolevel - as national and world economic systems;

- the subjects of influence differ depending on the level of the chosen economic system;

- the factors and instruments of influence also differ depending on the level of the chosen economic system and are divided into endogenous and exogenous in relation to this system.

We note a significant number of scientific studies on the economic development of all the above-mentioned levels of economic systems (Menčlová, 2014; Lankauskienė and Tvaronavičienè, 2013; Van den Berg, 2016). However, the most difficult is the study of the economic development of the world and national economies through a significant number of subjects, factors and tools of influence on the transformation of these systems. It is understandable that researchers seek to reduce the labour-intensity of these processes, identifying the main factors and tools of influence, which led to the emergence and development of economic development models based on a certain set of factors. In this case, the economic model shall be understood as the mathematical interpretation of the influence of a certain set of factors on the resultant indicator in the context of ensuring its longterm growth (Walker, 2013). Thus, one of the driving forces should be attributed to the influence factors, which positively or negatively affects the functioning of the economic system, and the resulting indicator is the key characteristic of this system, which can be quantitatively calculated.

Since the origination of economic science, there has been a rigorous discussion about the key influence factors and the resulting indicator of the development of economic systems, especially at the macrolevel, with the founders of such a discussion being the representatives of the classical school of political economy, which requires a detailed study of the transformation of both the influence factors and the resulting indicators in the economic development models, with their division into "old" and "new" models.

Figure 2. Graphic interpretation of defining the nature of the term "economic development"

Development
macrolevel) 


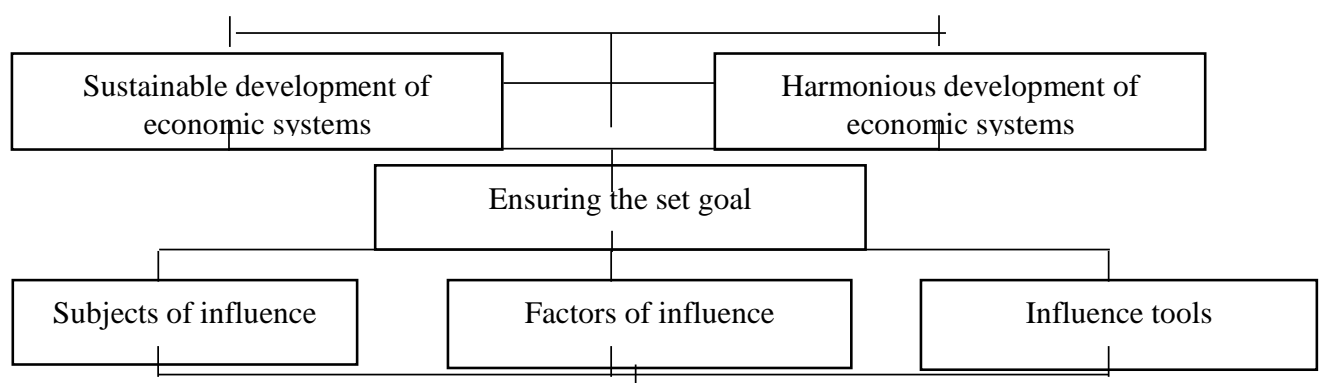

Economic development is a process of ensuring sustainable harmonious development of economic systems at the micro-, meso- and macrolevel, formed by the relevant subjects of influence with the use of a set of influence tools, and taking into account the aggregate of factors of influence on these systems in order to achieve the planned reference points for the transformation of such systems.

\subsection{Influence Factors in "Old" Economic Development Models}

Smith (1776) was one of the first to study macroeconomic development at the macrolevel (the level of a separate national economy). He emphasized that such growth occurs under the influence of two key endogenous factors: an increase in the level of capital accumulation and in productivity. In this case, the key resultant indicator was the wealth of people (income per capita). The scholar emphasized that economic development has no boundaries and may be continuous (Smith, 1776).

John von Neumann (1945) proposed to use a complex linear model of endogenous growth for the calculation of economic growth, with emphasis on such factors of production as labour and natural resources, being first to deal with the problem of natural resource shortage. Great Economic Depression has led to the emergence of a large number of economic development models that differed significantly from those of classical political economy and neoclassical scholars. J.M. Keynes (1936) emphasised the imbalances and crises in economic systems and the need to take into account, within the framework of economic development, the crisis response measures by governments of countries and unemployment rate. Schumpeter (1934), in support of J.M. Keynes's view of imbalances and crises in economic systems, believed that their development was leaping, where innovation was a key factor in the development. The transformation of world and national economies, as well as the critical reflection on the "old" economic development models, has led to new developments by scholars since the second half of the 20th century.

\subsection{Influence Factors in the "New" Economic Development Models}

The second half of the 20th century and the beginning of the 21 st century were accompanied by significant transformational processes in the world and national economies. At the same time, without denying the necessity of modelling economic development, the scholars criticized the existing models and offered their own ones 
with the relevant scientific novelty and practical value. However, there were also neoclassical economic development models, such as the linear endogenous AK model, which linked the final results with capital $(\mathrm{K})$ and the constant productivity parameter (A), focusing on such factors of influence as capital and labour, taking into account the capital ratio of one employee (Kurz and Salvadori, 2003).

We attribute the Ramsey-Cass-Koopmans model to neoclassical models, which explores consumer behaviour and household savings, which is related to the functioning of the business (capital, labour, labour productivity) and general economic equilibrium (Barro and Sala-i-Martin, 2004). In the same period, the differences in the economic development of developed and developing countries were being interpreted. Rostow (1971), studying the development of the countries, formed the theory of the stages of economic growth, singling out six stages, where the resultant indicator of the country's development was income per capita, and influence factors - a large number of technical and economic characteristics of the development of the national economy. It is also possible to distinguish the scientific achievements of Lewis (1956), who studies the problems of economic growth in developing countries and proposed his own model based on a two-sectoral economy (agrarian sector and industry), taking into account the interaction of these sectors in the capital and labour markets, as well as structural transformations in the economy as a whole. The growth of the role of innovation and human capital in economic development was reflected in the Uzawa-Lucas model, where, along with capital and labour, the level of education or the average level of human capital is recognized as a key influence factor (Lucas, 1988). The Mankiw-Romer-Weil (1990) model tried to combine building of an exogenous model of economic development with building of an endogenous model of such development.

There is an attempt to supplement or modernize the existing models with more modern economic development models, paying attention to certain features of this development:

- The Kremer's O-ring theory, developed in 1993, emphasizes the quality of staff training and the problem of labour mobility in the international labour market;

- The Silverberg-Verspagen model, which was proposed for use in 1997, takes into account competing technologies and innovations;

- The Dixit-Stiglitz-Krugman model, which was completed in 1999, focuses on the competitiveness of the economy, as well as the center - periphery interrelationship;

- The 2016 Gabriel-Jamie-Oreiro model is based on taking into account the territorial differences between the rich North and the poor South, the use of technology, structural changes and the real exchange rate;

- The 2017 Loubaki model emphasizes the influence of the fiscal policy of the state on its economic development (Loubaki, 2017; Yao, 2019; Gabriel, 2016). 
The beginning of the 21 st century is characterized by the increased attention of the scholars and economists- practitioners to the development of regions, which has led to the emergence of regional models of economic development.

\section{Discussion}

The study of economic development is one of the key in economic science, where we can note significant debates about the nature and components of such development, including the place of models and influence factors, which requires the verification of a number of hypotheses.

The first hypothesis was proved and offers the central place in the studies on the peculiarities of economic development to the relevant models, whose development began at the time of the classical school of political economy and which have their place in the scientific research of modern scholars. The vast majority of "old" models used only three factors (land, labor, capital) or their derivatives as influence factors, which formed the resulting indicator related to national income. The above did not allow taking into account the peculiarities of the country's development and the gradual transformation of economic systems within the growth of the role of information and innovations. This restriction has led to the development of "new models". We note that the second hypothesis is accepted in the work.

The scholar-developers of "new" economic development models tried to increase the number of influence factors in these models, however, in the majority of models three key factors that were used in the "old" models are still taken into account. The above suggests that the hypothesis is not proved. Regarding modern regional development models, we note that they have differences in the influence factors, but only some of them take into account the scale of their use, indicating that the hypothesis is partially proved. At the same time, we note the need to develop new economic development models that will take into account the peculiarities of the development of economically developed and developing countries. At the same time, we consider it necessary to form two models, namely:

- for developed countries:

$\mathrm{Y}=\mathrm{F}(\mathrm{K}, \mathrm{L}, \mathrm{I}, \mathrm{CA})$,

where $\mathrm{K}$ - capital, L - labour, I - level of innovations, CA - competitive advantages of the country.

- for developing countries:

$\mathrm{Y}=\mathrm{F}(\mathrm{K}, \mathrm{L}, \mathrm{I}, \mathrm{CA}, \mathrm{SE}, \mathrm{C})$, 
where SE - shadow economy level, C - corruption level.

Let us note the differences in influence factors that form economic development models for two types of countries; for developing countries it is important to take into account the shadow economy and corruption levels that have a significant impact on their development. The above shows that the last hypothesis is accepted.

Taking into account the above, we note that the research objective set at the beginning of this work is achieved. The key value of this research paper is the selection of key factors for the development of economic growth models for developed and developing countries, based on their critical assessment within the study of "old", "new" and regional models of growth. In this regard, some limitations in applying the results of this research paper can be distinguished, namely: the need to verify the proposed models and influence factors in practice with the possibility of adjustment; the difficulty of taking into account all the competitive advantages and corruption level in the economic development models. At the same time, the formulated limitations do not reduce the scientific and practical value of this research paper and outline the prospects for further study.

\section{Conclusions}

Modelling is of key importance in the study of economic development, especially macroeconomic systems. In this case, it is important to take into account the influence factors when forming these models. We note the transformation of influence factors in the economic development models during the research period in this field of economics with the factors that have not changed since the formation of the first models (labour, capital), as well as the need to develop new models that take into account the peculiarities of developed and developing countries.

The proposed economic development models and the aggregate of the influence factors used, which are based on a critical assessment of existing scientific developments on modelling of economic systems, will make it possible to more clearly predict the development of economies of different types. The practical implementation of the proposals and conclusions of this research paper should be considered in the context of their importance for improving the efficiency of the economies, especially those of the developing countries. Prospects for further research on the basis of the scientific results of this study are the following: verification in practice and revision of the proposed models and aggregate factors of influence on economic development; making a set of proposals for optimizing economic development for particular developing countries taking into account the modelling of the development. 


\section{References:}

Anushree, A. 2019. Models of Economic Growth (With Diagram): Macroeconomics, http://www.economicsdiscussion.net/economic-growth/models-economicgrowth/models-of-economic-growth-with-diagram-macroeconomics/26622.

Barro, R.J. \& Sala-i-Martin, X. 2004. Economic Growth. Cambridge, MA: The MIT Press.

Beck, U. 2005. Power in the Global Age: A New Global Political Economy. Cambridge: Policy Press.

Díaz-Bautista, A. \& González-Andrade, S. 2014. The debate of the modern theories of regional economic growth. Ra Ximhai. El Fuerte, Sinaloa, 10, No. 6, pp. 187-206.

Gabriel, L.F. 2016. A North-South model of economic growth, technological gap, structural change and real exchange rate. Structural Change and Economic Dynamics, Vol. 38, pp. 83-94.

Keynes, J.M. 1936. The general theory of employment, interest, and money. New York, Macmillan.

Kurz, H.D. \& Salvadori, N. 2003. Theories of Economic Growth - Old and New. In: The Theory of Economic Growth: A 'Classical'Perspective, 1-22, Edward Elgar.

Lankauskienè, T. \& Tvaronavičienè, M. 2013. Economic sector performance and growth: contemporary approaches in the context of sustainable development. Intellectual economics, Vol. 7, No. 3, pp. 355-374.

Leggett, J.A. \& Carter, N.T. 2012. Rio+ 20. The United Nations Conference on Sustainable Development, June 2012. Library of Congress, Congressional Research Service.

Lewis, A. 1956. The Theory of Economic Growth. Great Britain: George Allen \& Unwin.

Loubaki, D. 2017. The modern theory of economic development. International Journal of Economics, Business and Management Research, Vol. 1, No. 2, pp. 282-305.

Lucas, R.E. 1988. On the Mechanisms of Economic Development. Journal of Monetary Economics, Vol. 22, pp. 3-42.

Malthus, T.R. 1836. Principles of Political Economy. London: W. Pickering.

Mankiw, G., Romer, D. \& Weil, D. 1990. Contribution to the Empirics of Economic Growth. Cambridge, MA: NBER Working Paper.

Marshall, A. 1890. Principles of Economics. London: Macmillan.

Menčlová, B. 2014. Economic Development and Number of Business Entities. Český Finanční a účetní časopis, Vol. 4, pp. 166-174.

Moroianu, N. 2012. Models of the Economic Growth and their Relevance. Theoretical and Applied economics, Vol. 6, No. 6, pp. 135-142.

Piętak, Ł. 2014. Review of theories and models of economic growth. Comparative Economic Research, Vol. 1, pp. 45-60.

Plummer, P. \& Taylor, M. 2001. Theories of local economic growth (part 1): concepts, models, and measurement. Environment and Planning A, Vol. 33, pp. 219-236.

Proudhon, P.J. 1846. Systèm des contradictions économiques, ou, Philospohie de le misère. Paris: Guillaumin et cie.

Rostow, W. 1971. Politics and the Stages of Growth. Cambridge, MA: University Press.

Sanderson, W.C. 1992. Simulation Models of Economic, Demographic, and Environmental Interactions: Are They on a Sustainable Development Path? Working Paper of International Institute for Applied Systems Analysis.

Schumpeter, J. A. 1934. The Theory of Economic Development. Cambridge, MA: Harvard University Press. 
Sharipov, I. 2015. Contemporary Economic Growth Models And Theories: A Literature Review. CES Working Papers, Centre for European Studies, 7(3), pp. 759-773.

Smith, A. 1776. An Inquiry into the Nature and Causes of the Wealth of Nations. New York.

Van den Berg, H. 2016. Economic growth and development. World Scientific Publishing Company.

Von Neumann, J. 1945. A Model of General Economic Equilibrium. Review of Economic Studies, Vol. 13, pp. 1-9.

Walker, J.R. 2013. Macroeconomic Models of Economic Growth. U. of Wisconsin, https://www.ssc.wisc.edu/ walker/wp/wpcontent/uploads/2013/09/E448lec7slides.

Yao, P. 2019. Modern theories of economic development. HECER-WIDER Development Economics. Aalto University. 